\title{
Bulleyaconitine A inhibits morphine physical and psychological dependence via dynorphin A expression
}

\author{
Meng-Jing Zhao ${ }^{1}$, Mi-Ya Wang ${ }^{2}$, Le Ma ${ }^{3}$, Khalil Ali Ahmad ${ }^{3}$, and Yong-xiang Wang ${ }^{1}$ \\ ${ }^{1}$ Shanghai Jiao Tong University \\ ${ }^{2}$ East China Normal University \\ ${ }^{3}$ Shanghai Jiaotong University
}

July 1, 2020

\begin{abstract}
Background and purpose: Drug addiction is a chronic and recurrent brain disease, which has become a social problem in recent years. Our study investigated Bulleyaconitine A (BAA) inhibition in physical and psychological dependence and explored underlying mechanisms of action. Experiment approach: Naloxone-induces withdrawal signs in morphine mice and conditioned place preference (CPP) paradigm were used. Prodynorphin gene expression and dynorphin A level were measured in nucleus accumbens (NAc) and hippocampal CA1. Double immunofluorescence staining of dynorphin A with glia and neuronal cellular biomarkers was detected in NAc and hippocampal CA1. Key results: 1 Multiple daily injections of morphine in mice induced withdrawal signs and conditioned place preference (CPP) acquisition. 2 Single subcutaneous injection of BAA (30-300 $\mu \mathrm{g} / \mathrm{kg})$ dose-dependently and attenuated morphine withdrawal signs, and BAA (300 $\mathrm{gg} / \mathrm{kg})$ also totally alleviated morphine CPP acquisition. 3 BAA specifically stimulated the expression of dynorphin A in microglia in NAc and hippocampal CA1, measured by gene and protein expression and double immunofluorescence staining. 4 BAA-inhibited naloxone-induced withdrawal signs and CPP acquisition were totally blocked by the microglial activation inhibitor minocycline, dynorphin A antiserum and specific $x$-opioid receptor antagonist GNTI. Conclusions \& implications: Our results, for the first time, illustrate that BAA attenuates morphine-induced physical and psychological dependence by stimulation of microglial dynorphin A expression in brain and suggest that BBA may be a potential candidate for the treatment of opioid drug addiction. Keywords: BAA, dynorphin A, x-opioid receptor, nucleus accumbens (NAc), hippocampal CA1, microglia
\end{abstract}

\section{Introduction}

Drug addiction is a chronic and recurrent brain disease, which is characterized by compulsive seeking drug and intense drug craving (Shippenberg et al., 2007a; Zhu et al., 2015; Wu et al., 2016). Opioid addiction is the accumulated results of tolerance and dependence, mainly including physical dependence and psychological dependence. Physical dependence seeks drug repeatedly and increases gradually the dose of the drug to avoid withdrawal symptoms (Nestler et al., 1993). Psychological dependence refers to the craving for seeking drug and euphoria achieved by repeated medication, which is not easy to eliminate, prompting to relapse. Drug relapse can persist a long time after the cessation of drug use in the human (Robbins et al., 2008) and the high rate of relapse after detoxification is a major clinical problem and becomes severe challenge to treat drug abuse (Aguilar et al., 2009). Morphine and related opioids are the most potent and widely used analgesics for treating moderate to severe pain. However, the development of physical and psychological dependence is an important limitation to use opioid drugs in the treatment of chronic pain, leading to misappropriate use and abuse liability (Ruzza et al., 2019). Drug addiction in western countries particularly in the USA has become a health and social problem in recent years that needs to be urgently addressed and is a unmet medical need (Wingo et al., 2016; Ezard et al., 2018). 
Widely distributed in the central nervous system, dynorphin A binds to three opioid subtypes with different affinities, especially to $x$-opioid receptors (Fallon and Leslie, 1986; Schwarzer, 2009). $x$-Opioid receptors are also widely distributed in the central nervous system (Yuferov et al., 2004; Shippenberg et al., 2007b; Bruchas et al., 2010), and the dynorphin/ $x$-opioid receptor system plays an important role in pain/analgesia, temperature, emotions and neuroendocrine functions (Pfeiffer et al., 1986; Bodnar, 2010). The dynorphin/x-opioid receptor pathway is also a major anti-reward system and participates the development of drug addiction. There is growing evidence that administration of dynorphin A and other related opioid peptides alleviates withdrawal symptoms of morphine physical dependence (Takemori et al., 1993; Hooke et al., 1995). $x$-Opioid agonists, do not produce reinforcing effects but reduce drug abuse under certain conditions. It was reported that the $x$-opioid receptor agonists ethylketocyclazocine and U50,488 attenuated cocaine behavioral sensitization, conditioned place preference (CPP) acquisition and self-administration in rhesus monkeys by repressing the release of dopamine (Maisonneuve et al., 1994). It was also reported that the dynorphin/ $x$-opioid receptor system antagonized rewarding effects in drug abuse and inhibited brain reward function by suppressing dopamine release from the mesolimbic reward pathway (Chartoff et al., 2008; Mysels and Sullivan, 2009). On the contrary, it was reported that $x$-opioid receptor antagonists nor-BNI and arodyn blocked stress-induced reinstatement of cocaine-induced self-administration or CPP acquisition (Beardsley et al., 2005; Carey et al., 2007). These reports suggest a complex role of the dynorphin/ $x$-opioid receptor system in the drug abuse development.

Bulleyaconitine A (BAA), isolated from the rhizomes of Aconitum bulleyanum, is a C19-diterpenoid alkaloid without activities of binding to opioid receptors (Wang et al., 2007). As it is a nonnarcotic analgesic and has lower toxicity and wider treatment window than aconitine, BAA has been widely prescribed in China to treat various forms of chronic pain over four decades (Bello-Ramirez and Nava-Ocampo, 2004; Xie et al., 2018). Accumulated evidence demonstrated that BAA and its analogs aconitine (C19-diterpenoid), bullatine A (C20-diterpenoid) and lappaconitine (C18-diterpenoid) produced antinociception without induction of antinociceptive tolerance in various rodent models of pain hypersensitivity, including neuropathic pain, bone cancer pain, inflammatory pain, diabetic pain, and visceral pain (Li et al., 2016a; Li et al., 2016b; Huang et al., 2017a; Huang et al., 2020a; Huang et al., 2020b). Our recent studies further uncovered that BAA, aconitines, bullatine $\mathrm{A}$ and lappaconitine alleviated pain directly through stimulating spinal microglial dynorphin A expression and subsequent activating $\chi$-opioid receptors in a variety of rodent models of pain hypersensitivity (Huang et al., 2017a; Li et al., 2017; Sun et al., 2018). In addition, BAA and bullatine A injection blocks chronic morphine-induced antinociceptive tolerance in rats and mice (Li et al., 2016a; Huang et al., 2017a). These reports lead to the hypothesis that aconitines including BAA may have potential therapeutic properties in the treatment of morphine physical dependence and psychological dependence.

In this study we aimed to assess the anti-addictive effects of BAA in morphine-induced physical and psychological dependence. We first tested whether subcutaneous injection of BAA attenuated morphine-induced physical dependence in a mouse model, in which application of naloxone induced withdrawal signs including shakes, jumps, genital licks, fecal excretion and body weight loss (Lenard and Roerig, 2005). We further assessed whether subcutaneous BAA inhibited morphine-induced psychological dependence in the CPP test, a widely used model to assess the reinforcing effect of drugs of abuse in laboratories (Wu et al., 2016). As like other addictive drugs, morphine CPP acquisition is considered to constitute a part of the addiction process associated with the opioid reinforcing properties. Finally, we explored the mechanisms underlying BAA-induced anti-addictive effects, particularly the involvement of microglial dynorphin A expression and subsequent $x$-opioid receptor activation in brain. Our results, for the first time, uncover that BAA inhibits morphine-induced physical and psychological dependence through brain microglial expression of dynorphin A, and suggest that microglial expression of dynorphin A is a potential target for the treatment of opioid addiction and abuse.

\section{Materials and methods}

2.1. Drugs and reagents . Bulleyaconitine A (BAA) was purchased from Zelang Bio-Pharmaceutical (Nanjing, China) with the purity no less than $98 \%$ determined by manufacturer with high performance liquid 
chromatography. Morphine hydrochloride, minocycline, and pentobarbital sodium were purchased from the Northeast Pharmaceuticals Group (Shenyang, China), Yuanye Biotech (Shanghai, China), and Sinopharm Chemical Reagent Co. (Shanghai, China), respectively. Both 5'-guanidinonaltrindole (GNTI) and naloxone hydrochloride were obtained from Sigma-Aldrich (St. Louis, Mo, USA). The rabbit polyclonal antiserum neutralizing dynorphin A was purchased from Phoenix Pharmaceuticals (Burlingame, CA, USA). The antiserum was specific to dynorphin A (100\%), but not to dynorphin B (0\%), $\beta$-endorphin $(0 \%), \alpha$-neo-endorphin $(0 \%)$ or leu-enkephalin $(0 \%)$ according to the manufacturer's data sheet. Its specificity was also validated by the antigen absorption test from other laboratories (Wakabayashi et al., 2010; Yamada et al., 2013). All the drugs and reagents were dissolved or diluted in $0.9 \%$ normal saline.

2.2. Experimental animals . Male adult Swiss mice (8-9 weeks, 20-25 g) were purchase from the Shanghai Experimental Animal Institute for Biological Sciences (Shanghai, China). The animals were maintained in a 12-hr light/dark cycle (light period 7:00 a.m.-7:00 p.m.) with free access to food and water at standard room temperature (22 \pm 2 ) in the Shanghai Jiao Tong University Experimental Animal Center (Shanghai, China). All mice were acclimatized to 3-5 days before the experiments. Mice ( $\mathrm{n}=10-12$ per group) were randomly assigned and the behavior tests were performed in a blind manner. All housing conditions and experimental procedures were approved by the Animal Care and Welfare Committee of Shanghai Jiao Tong University (Shanghai, China).

2.3. Induction of morphine physical dependence. The morphine administration paradigm for induction of physical dependence was performed as previously established (Goeldner et al., 2011; Bobzean et al., 2019). Briefly, morphine was administered in mice with escalating doses $(5,10,20,40,80$ and $100 \mathrm{mg} / \mathrm{kg}$ ) by twice-daily subcutaneous injections at 10:00 a.m. and 4:00 p.m. for 6 consecutive days. On the seventh day, mice received a single subcutaneous injection of morphine $(100 \mathrm{mg} / \mathrm{kg})$ at 10:00 a.m. followed by an intraperitoneal injection of naloxone $(5 \mathrm{mg} / \mathrm{kg}) 4$ hours later. The withdrawal signs included shakes, jumps, genital licks and fecal excretion and loss of body weight, which were observed and recorded for 30 minutes after naloxone injection.

2.4. CPP apparatus and paradigm. CPP has a position preference for different chambers and is used to explore the effects of drug rewarding (Bahi et al., 2008; Shi et al., 2019). The apparatus for the CPP test consisted of three compartments. Two equal-sized chambers $(25 \times 25 \times 40 \mathrm{~cm})$ with a connecting white protruded chamber (null compartment, $25 \times 5 \times 40 \mathrm{~cm}$ ) were separated by a removable door. To distinguish each other, one of the main chambers was decorated with black walls and a striped floor, while the other one was with black and white striped walls and a round dot floor. The environmental lighting was adjusted to exclude baseline preference. The apparatus was kept in a quiet room and dim 40 lx illumination (Marszalek-Grabska et al., 2018).

The 10-day schedule CPP paradigm included three distinct phases: preconditioning, conditioning and postconditioning (Khaleghzadeh-Ahangar and Haghparast, 2015, 2017). The preconditioning phase started with a 3-day twice-daily (10:00 a.m. and 4:00 p.m.) mouse handling with the cupping open gloved hand method (Gouveia and Hurst). On Day 4, each mouse was placed into the null compartment with full access to the entire apparatus for 15 minutes. The time spent in each chamber was recorded by a 3CCD camera (Panasonic Inc, Japan) and analyzed using the EthoVision XT 8.0 (Noldus Information Technology Co., China) to determine baseline preference. Animals that spent more than 450 seconds in any of the three chambers were excluded from the study. During the conditioning phase, mice underwent 5 days of morphine $(10 \mathrm{mg} / \mathrm{kg})$ or saline $(10 \mathrm{~mL} / \mathrm{kg})$ alternate subcutaneous injections, with a 6-hour interval (between 10:00 a.m. and 4:00 p.m.) and included ten 45-min sessions in a five-day schedule. On day 5, 7 and 9 of conditioning, mice were treated with morphine in the morning and immediately confined to the morphine-paired chamber for 45 minutes and received saline in the afternoon and put in the saline-paired chamber for 45 minutes. On day 6 and 8, the injection time of morphine and saline was changed (Meng et al., 2012; Shirazy et al., 2020). Morphine-induced CPP in mice was tested by being allowed with free access to all three compartments for 15 minutes in the post-conditioning phase (On Day 10). The time spent in each chamber was recorded by the $3 \mathrm{CCD}$ camera and analyzed using the EthoVision XT 8.0. The conditioning score was expressed by the 
time spent in the drug-paired chamber minus the time spent in the saline-paired chamber.

2.5.Intracerebroventricular catheterization and injection in mice. For intracerebroventricular injection, mice were anesthetized by intraperitoneal injection of $1.5 \%$ pentobarbital sodium and positioned in a stereotaxic instrument (Stoelting Company, Wood Dale, IL, USA). The surgical site was shaved and sterilized with $70 \%$ ethanol and a $1.5 \mathrm{~cm}$ incision was made to expose the skull. A 22-gauge stainless steel cannula was directed to $0.6 \mathrm{~mm}$ lateral and $1.0 \mathrm{~mm}$ caudal to bregma and inserted $3 \mathrm{~mm}$ deep. Dental cement was applied to adhere the cannula to the skull. The incision was sutured and the cap of cannula was covered. Animals were returned to their cages and allowed at least 3 days recovery. The drug was administrated slowly over 3 minutes in a volume of $6 \mu \mathrm{L}$ through the planted cannula, using an insulin needle mated with a $10-\mu \mathrm{L}$ microsyringe via a polyethylene tube (Hylden and Wilcox, 1980; Lenard and Roerig, 2005).

2.6. $R N A$ extraction, reverse transcription, andreal-time quantitative polymerase chain reaction (PCR). The total RNAs were isolated from nucleus accumbens (NAc) and hippocampus of mice using the TRIzol reagent (Invitrogen, Carlsbad, USA) and were reversely transcribed into cDNA using the ReverTraAce RT-qPCR kit (Toyobo Co., Osaka, Japan) according to the instructions provided by the manufacturers. Real-time quantitative PCR was performed with a Mastercycler ep realplex (Eppendorf, Hamburg, Germany) using the Realmaster Mix (SYBR Green I, Toyobo, Japan). The forward and reverse primer sequences were ATG ATG AGA CGC CAT CCT TC and TTA ATG AGG GCT GTG GGA AC for prodynorphin, which was designed by Premier 6 (version 6.0, Premier Biosoft, San Francisco, USA); and CCA AGG TCA TCC ATG ACG AC and TCC ACA GTC TTC TGA GTG GC for gapdh (Reiss et al., 2017). The fold change was calculated using the $2^{-\mathrm{t}}$ method after normalization to gapdh (Huang et al., 2017b).

2.7. Measurement of dynorphin A . NAc and hippocampus were obtained and immediately frozen in liquid nitrogen and stored an - 80 until further measurement. Tissues were homogenized at $4000 \mathrm{rpm}$ for 15 seconds with a homogenizer (Fluko Equipment Co, Shanghai, China) in $10 \mathrm{mM}$ Tris- $\mathrm{HCl}(\mathrm{pH} 7.4)$ and centrifuged at $1500 \mathrm{rpm}$ at 4 for 15 minutes. The total protein concentrations in NAc and hippocampus were determined by standard bicinchoninic acid protein assay (Beyotime Institute of Biotechnology, Jiangsu, China) and dynorphin A was assayed using commercialized fluorescence enzyme-linked immunosorbent assay (ELISA) kit (Phoenix Pharmaceuticals, Burlingame, CA, USA) according to the operation manual (Leitermann et al., 2004; Nocjar et al., 2012).

2.8.Immunofluorescence staining . Double immunofluorescence labeling of dynorphin A and cellular biomarkers of microglia, astrocytes, and neurons in NAc and hippocampus was carried out using a TCS SP8 confocal microscope (Leica Microsystems, Wetzlar, Germany) according to the previously published method with minor modifications. Mice were deeply anesthetized by intraperitoneal $1.5 \%$ pentobarbital sodium $(5 \mathrm{~mL} / \mathrm{kg})$, and intracardially perfusion with $20 \mathrm{~mL}$ of $0.9 \%$ saline, followed by $20 \mathrm{~mL}$ of $4 \%$ paraformaldehyde. The brain was dissected and fixed in the $4 \%$ paraformaldehyde for 12 hours at 4 . Paraformaldehyde was then removed with PBS and the brain was dehydrated with gradient sucrose solution $(10 \%, 20 \%$ and $30 \%$ diluted with PBS) at 4 . The dehydrated brain was embedded in the optimal cutting temperature embedding agent (Lecia Microsystems) and cut into 30- $\mu \mathrm{m}$-thick transverse sections with sliding microtome. The frozen sections were incubated in $10 \%$ goat serum $(\mathrm{v} / \mathrm{v})$ and $0.5 \%$ Trixon X-100 (v/v) for 1 hour at room temperature and then incubated at 4 for 24 hours with primary antibodies. The applied primary antibodies included dynorphin A antibody (1:100; rabbit polyclonal; Phoenix Pharmaceuticals) and cellular markers: Iba-1 (1:100; mouse monoclonal; Millipore, Darmstadt, Germany) for microglia, GFAP (1:100; mouse monoclonal) for astrocytes and NeuN (1:60; mouse polyclonal; Millipore) for neurons. After washing with PBS, the sections were incubated for 1 hour at 37 with the Alexa-555-conjugated goat anti-rabbit secondary antibody for dynorphin A and the Alexa-488-conjugated goat anti-mouse secondary antibody for microglia, astrocytes or neurons (Qi et al., 2018). Expression of dynorphin A, Iba-1, GFAP, and NeuN was visualized in the shell of nucleus accumbens (NAcSh) (from bregma $1.70 \mathrm{~mm}$ to $0.98 \mathrm{~mm}$, according to the brain in stereotaxic coordinates) and hippocampal CA1 (from bregma $-1.46 \mathrm{~mm}$ to $-1.94 \mathrm{~mm}$, according to the brain stereotaxic coordinates) under a confocal microscope. To quantify the relative intensity of dynorphin A in Iba-1-, GFAP- or NeuN-immunopositive cells in NAcSh and hippocampal CA1, the images were acquired 
at a $10 \times$ or $30 \times$ magnification. The background fluorescence was excluded and only immunofluorescent intensity from positively stained areas were included using the low and high thresholds. A colocalization analysis was performed using the ImageJ software with a co-localization finder to generate images in which co-localized pixels appeared as white. All surface areas in each group were measured following the same setup configurations at the same time. The averaged value of the immunolabeled surface area was recorded as the positive immunofluorescence area from three nonadjacent sections of NAcSh or hippocampal CA1. Data was calculated from six mice of each group.

2.9. Statistical analysis . For the dose-response curve analysis, the parameters, i.e., minimum effect, halfeffective dose $\left(\mathrm{ED}_{50}\right), \mathrm{E}_{\max }$ and Hill coefficient $(\mathrm{n})$, were calculated by fitting nonlinear least-squares curves to the relation $\mathrm{Y}=\mathrm{a}+\mathrm{bx}$, where $\mathrm{x}=[\mathrm{D}]^{\mathrm{n}} /\left(\mathrm{ED}_{50}{ }^{\mathrm{n}}+[\mathrm{D}]^{\mathrm{n}}\right)$. The values of $\mathrm{ED}_{50}$ and $\mathrm{b}\left(\mathrm{E}_{\max }\right)$ were projected by yielding a minimum residual sum of squares of deviations from the theoretical curve (Zhang et al., 2013).

The data were summarized as means \pm standard error of the mean (S.E.M.). The statistical significance was evaluated by unpaired and two-tailed Student t-test or one-way analysis of variance (ANOVA) using Prism (version 7.00, GraphPad Software Inc., San Diego, CA, USA). The ANOVA analysis was undertaken based on the assumptions of normal distribution and variance consistency verified by residual plots and the post-hoc Student-Newman-Keuls test was performed when the effect of the drug (dose) was observed to be statistically significant. The probability values were two-tailed and the statistical significance criterion value was 0.05 .

\section{Results}

3.1.B AA attenuated naloxone-induced withdrawal signs in morphine physical dependence. Six groups of mice ( $\mathrm{n}=10$ per group) were subjected to bi-daily subcutaneous injections of normal saline $(10 \mathrm{~mL} / \mathrm{kg})$, BAA $(300 \mu \mathrm{g} / \mathrm{kg}$ ) or morphine (escalating doses of 5, 10, 20, 40, 80 and $100 \mathrm{mg} / \mathrm{kg}$ ) for 7 days. On the $7 \mathrm{th}$ day, mice received intraperitoneal injection of naloxone $(5 \mathrm{mg} / \mathrm{kg}) 4$ hours post the last injection of morphine $(100 \mathrm{mg} / \mathrm{kg})$ to induce physical dependence, and their withdrawal signs were observed immediately for 30 minutes. For the BAA inhibitory effects, the mice received a single injection of saline $(10 \mathrm{~mL} / \mathrm{kg})$ or BAA $(30,100$ or $300 \mu \mathrm{g} / \mathrm{kg}) 40$ minutes prior to the intraperitoneal injection of naloxone. As shown in Fig. 1, intraperitoneal injection of naloxone did not induce any abnormal behaviors in bi-daily saline- or BAAtreated mice. In contrast, naloxone in bi-daily morphine injected mice induced profound withdrawal signs including shakes (Fig. 1A), jumps (Fig. 1B), genital licks (Fig. 1C), fecal excretion (Fig. 1D) and body weight loss (Fig. 1E) $(\mathrm{P}<0.05$, by one-way ANOVA followed by the post-hoc Student-Newman-Keuls test). Moreover, pretreatment with subcutaneous injection of BAA $(30,100$ and $300 \mu \mathrm{g} / \mathrm{kg}$ ) dose-dependently attenuated naloxone-induced withdrawal signs in bi-daily morphine-treated mice, with maximal inhibition of around $70-100 \%$ in each different sign $(\mathrm{P}<0.05$, by one-way ANOVA followed by the post-hoc StudentNewman-Keuls test). The dose-response analysis was performed in shakes with an $\mathrm{ED}_{50}$ of $74.4 \mu \mathrm{g} / \mathrm{kg}$ which was yielded after data transformation (Fig. 1A), and in the body weight loss with an $\mathrm{ED}_{50}$ of $105.8 \mu \mathrm{g} / \mathrm{kg}$ after data transformation (Fig. 1E).

3.2.BAA attenuated morphine-induced CPP acquisition . Four groups of mice ( $\mathrm{n}=12$ per group) were subjected to the preconditioning phase of three days and the place preference test on the $4^{\text {th }}$ day followed by alternate daily subcutaneous injections of normal saline $(10 \mathrm{~mL} / \mathrm{kg})$, BAA $(300 \mu \mathrm{g} / \mathrm{kg})$ or morphine $(10$ $\mathrm{mg} / \mathrm{kg})$ for 5 days. On the $10^{\text {th }}$ day, mice received single subcutaneous injection of saline $(10 \mathrm{~mL} / \mathrm{kg})$ or BAA $(300 \mu \mathrm{g} / \mathrm{kg}) 50$ minutes prior to the last injection and the place preference test was conducted immediately afterwards. As shown in Fig. 2, all four groups of mice did not show any obvious CPP acquisition in the preconditioning phase. Moreover, bi-daily subcutaneous injections of saline did not exhibit significant CPP acquisition in the post-conditioning phase. In contrast, bi-daily injections of morphine but not BAA showed remarkable CPP acquisition. However, pretreatment with subcutaneous injection of BAA completely attenuated morphine-induced $\mathrm{CPP}$ acquisition $(\mathrm{P}<0.05$, by one-way ANOVA followed by the post-hoc Student-Newman-Keuls test).

3.3. BAA specifically stimulated microglial dynorphin A expression in NAc andhippocampus in morphine- 
multiply treated mice. Two groups of mice ( $\mathrm{n}=10$ per group) daily treated with morphine $(10 \mathrm{mg} / \mathrm{kg})$ for 5 days received subcutaneous injection of normal saline $(10 \mathrm{~mL} / \mathrm{kg})$ or BAA $(300 \mu \mathrm{g} / \mathrm{kg})$. Mice were sacrificed 1 hour after subcutaneous injection and NAc and hippocampus were obtained for the prodynorphin mRNA detection using RT-PCR. As shown, treatment with BAA significantly increased prodynorphin gene expression by 1.9 -fold in NAc (Fig. 3A) and 1.7-fold in hippocampus (Fig. 3B), respectively ( $\mathrm{P}<0.05$, by unpaired and two-tailed Student t-test). The stimulatory effects of BAA on dynorphin A protein expression were also measured in NAc and hippocampus in the same mice using the commercial fluorescent ELISA kit. As exhibited, subcutaneous BAA significantly increased dynorphin A expression in NAc $(\mathrm{P}<0.05$, by unpaired and two-tailed Student t-test; Fig. 3C) and hippocampus $(\mathrm{P}=0.07$, by unpaired and two-tailed Student t-test; Fig. 3D).

Dynorphin A is known to be localized in neurons, astrocytes and microglia in the central nervous system (Wahlert et al., 2013; Ayrout et al., 2019). To verify cell types that specifically upregulate dynorphin A expression in NAcSh and hippocampal CA1 following BAA treatment, dynorphin A was immunofluorescent labeled with the microglial cellular marker Iba-1, astrocytic cellular marker GFAP and neuronal cellular marker NeuN. Two groups of mice ( $\mathrm{n}=6$ per group) daily treated with morphine $(10 \mathrm{mg} / \mathrm{kg})$ for 5 days received subcutaneous injection of saline $(10 \mathrm{~mL} / \mathrm{kg})$ or BAA $(300 \mu \mathrm{g} / \mathrm{kg})$. Mice were sacrificed 1 hour after the subcutaneous injection and NAcSh and hippocampal CA1 were obtained for fluorescent immunostaining. As shown, dynorphin A was colocalized with Iba-1, GFAP and NeuN in NAcSh of saline-treated mice (Fig. 4A-4F). Subcutaneous BAA specifically increased co-labeling of dynorphin A/Iba-1 (Fig. G, H) but not dynorphin A/GFAP (Fig. I, J) or dynorphin A/NeuN (Fig. K, L) at $10 \times$ and $30 \times$ magnification. In addition, the ImageJ software was used to quantify immunofluorescence intensity of dynorphin A with Iba-1, GFAP or NeuN at $10 \times$ magnification. Treatment with subcutaneous BAA significantly increased dynorphin A/Iba1 by 2.4 -fold $(\mathrm{P}<0.05$, by unpaired and two-tailed Student t-test; Fig. $4 \mathrm{M})$, but not dynorphin A/GFAP (Fig. $4 \mathrm{~N}$ ) or dynorphin A/NeuN (Fig. 4O). Furthermore, the same specific stimulatory effects of BAA on microglial dynorphin A expression were observed in hippocampal CA1 from the same mice as above (Fig. $5 \mathrm{~A}-5 \mathrm{~L})$, with increased immunofluorescence intensity of dynorphin A/Iba-1 by 1.9 -fold $(\mathrm{P}<0.05$, by unpaired and two-tailed Student t-test; Fig. 5M), but not dynorphin A/GFAP (Fig. 5N) or dynorphin A/NeuN (Fig. $5 \mathrm{O})$.

3.4. Brain microglial expression of dynorphin A mediated BBA-inhibited morphine dependence. To verify the causal relationship between the microglial expression of dynorphin A in brain and BAA-inhibited morphine physical dependence, the microglial activation inhibitor minocycline (Wu et al., 2002; Kobayashi et al., 2013), dynorphin A antiserum (Li et al., 2016) and $x$-opioid receptor antagonist GNTI (Zhang et al., 2007; Liu et al., 2013) were intracerebroventricularly injected separately. Four groups of morphine physical dependence mice $(\mathrm{n}=10$ per group) received the first intracerebroventricular injection followed by the second subcutaneous injection of 1) saline $(6 \mu \mathrm{L})+$ saline $(10 \mathrm{~mL} / \mathrm{kg}), 2)$ minocycline $(10 \mu \mathrm{g})+$ saline $(10 \mathrm{~mL} / \mathrm{kg}), 3)$ saline $(6 \mu \mathrm{L})+$ BAA $(300 \mu \mathrm{g} / \mathrm{kg})$, and 4) minocycline $(10 \mu \mathrm{g})+$ BAA $(300 \mu \mathrm{g} / \mathrm{kg})$. The second subcutaneous injection was 4 hours post the first intracerebroventricular injection. Withdrawal signs were precipitated by intraperitoneal injection of naloxone $(5 \mathrm{mg} / \mathrm{kg}) 40$ minutes after subcutaneous injection. As shown in Fig. 6A-6E, subcutaneous injection of BAA in morphine physical dependence mice significantly attenuated naloxone-induced withdrawal signs including shakes, jumps, genital licks, fecal excretions and body weight loss; whereas intracerebroventricular minocycline failed to influence morphine-induced physical dependence. However, pretreatment with intracerebroventricular minocycline nearly completely restored systemic BAAsuppressed withdrawal signs $(\mathrm{P}<0.05$, by one-way ANOVA followed by the post-hoc Student-Newman-Keuls test).

Additional four groups of morphine physical dependence mice ( $\mathrm{n}=10$ per group) received the first intracerebroventricular injection followed by the second subcutaneous injection of 1) saline $(6 \mu \mathrm{L})+$ saline $(10$ $\mathrm{mL} / \mathrm{kg}), 2)$ dynorphin A antiserum (1:30 dilution, $6 \mu \mathrm{L})+$ saline $(10 \mathrm{~mL} / \mathrm{kg}), 3)$ saline $(6 \mu \mathrm{L})+$ BAA $(300$ $\mu \mathrm{g} / \mathrm{kg})$ and 4$)$ dynorphin A antiserum (1:30 dilution, $6 \mu \mathrm{L})+$ BAA $(300 \mu \mathrm{g} / \mathrm{kg})$. The second subcutaneous injection was 30 minutes post the first intracerebroventricular injection. Withdrawal signs were precipitated by intraperitoneal injection of naloxone $(5 \mathrm{mg} / \mathrm{kg}$, $) 40$ minutes after subcutaneous injection. Subcutaneous 
injection of BAA in morphine physical dependence mice attenuated naloxone-induced withdrawal signs. Intracerebroventricular injection of the dynorphin A antiserum did not significantly affect baseline morphine physical dependence, but reemerged naloxone-induced withdrawal syndrome from BAA inhibition $(\mathrm{P}<0.05$, by one-way ANOVA followed by the post-hoc Student-Newman-Keuls test; Fig. 6F-6J).

Further four groups of morphine physical dependence mice ( $n=10$ per group) received the same pattern as above except that intracerebroventricular injection of the dynorphin A antiserum was replaced with GNTI $(5 \mu \mathrm{g})$. As displayed in Fig. 6K-6O, intracerebroventricular injection of GNTI predominantly restored BAA-suppressed morphine physical dependence $(\mathrm{P}<0.05$, by one-way ANOVA followed by the post-hoc Student-Newman-Keuls test), although it did not significantly alter naloxone-induced withdrawal signs in baseline physical dependence.

3.5. Brain microglial expression of dynorphin A mediated BAA-inhibited CPP acquisition. Same as in the physical dependence model, minocycline, dynorphin A antiserum and GNTI were intracerebroventricularly injected separately into the morphine CPP acquisition mice in order to determine whether microglial expression of dynorphin A in brain contributed to BAA-inhibited morphine CPP acquisition. Four groups of morphine-induced CPP mice ( $\mathrm{n}=10$ per group) were first intracerebroventricularly injected followed 4 hours later by subcutaneous injected with 1$)$ saline $(6 \mu \mathrm{L})+$ saline $(10 \mathrm{~mL} / \mathrm{kg}), 2)$ minocycline $(10 \mu \mathrm{g})+$ saline $(10 \mathrm{~mL} / \mathrm{kg}), 3)$ saline $(6 \mu \mathrm{L})+$ BAA $(300 \mu \mathrm{g} / \mathrm{kg})$, and 4) minocycline $(10 \mu \mathrm{g})+$ BAA $(300 \mu \mathrm{g} / \mathrm{kg})$. The place preference test was assessed 50 minutes subsequent to subcutaneous injection. As shown in Fig. 7A, subcutaneous injection of BAA but not intracerebroventricular minocycline completely attenuated morphine $\mathrm{CPP}$ acquisition. However, pretreatment with intracerebroventricular minocycline entirely restored BAAsuppressed CPP acquisition $(\mathrm{P}<0.05$, by one-way ANOVA followed by the post-hoc Student-Newman-Keuls test).

In addition, four groups of morphine CPP mice ( $\mathrm{n}=10$ per group) were first intracerebroventricularly injected 0.5 hours later followed by subcutaneous injected with 1$)$ saline $(6 \mu \mathrm{L})+$ saline $(10 \mathrm{~mL} / \mathrm{kg}), 2)$ the dynorphin A (1:30 dilution, $10 \mu \mathrm{L})+$ saline $(10 \mathrm{~mL} / \mathrm{kg}), 3)$ saline $(6 \mu \mathrm{L})+$ BAA $(300 \mu \mathrm{g} / \mathrm{kg})$, and 4$)$ the dynorphin A (1:30 dilution, $10 \mu \mathrm{L})+$ BAA $(300 \mu \mathrm{g} / \mathrm{kg})$. The place preference test was assessed 50 minutes subsequent to subcutaneous injection. Subcutaneous injection of BAA but not intracerebroventricular the dynorphin A antiserum totally inhibited morphine CPP acquisition. However, pretreatment with intracerebroventricular injection of the dynorphin A antiserum completely attenuated BAA-suppressed morphine CPP acquisition $(\mathrm{P}<0.05$, by one-way ANOVA followed by the post-hoc Student-Newman-Keuls test; Fig. 7B).

Last four groups of morphine CPP mice ( $\mathrm{n}=10$ per group) received the same regimen as above except that intracerebroventricular injection of the dynorphin A antiserum was replaced with GNTI $(5 \mu \mathrm{g})$. As exhibited in Fig. 7C, intracerebroventricular injection of GNTI did not have a significant inhibitory effect on morphine $\mathrm{CPP}$ acquisition, but almost totally restored systemic BAA-suppressed morphine-induced CPP acquisition ( $\mathrm{P}=0.09$, by one-way ANOVA followed by the post-hoc Student-Newman-Keuls test).

\section{Discussion}

Long-term application of morphine and other opioid narcotics induces addiction composing physical and psychological dependence. In the present study, physical dependence developed following bi-daily subcutaneous injections of morphine in mice for 7 consecutive days, and application of naloxone induced withdrawal signs including shakes, jumps, genital licks, fecal excretion and body weight loss. In contrast, bi-daily subcutaneous injections of BAA up to $300 \mu \mathrm{g} / \mathrm{kg} /$ day for 7 days did not induce any physical dependence, consistent with the previous finding in which daily subcutaneous BAA did not induce jumping responses following nalorphine challenge (Tang et al., 1986). In addition, single subcutaneous injection of BAA alleviated naloxone-induced withdrawal signs in morphine physical dependence mice. In doses ranging from 30 to $300 \mu \mathrm{g} / \mathrm{kg}$ in morphine dependence mice, BAA caused a dose-related inhibition of abrupt withdrawal signs, typically shakes and body weight loss with $\mathrm{ED}_{50}$ values of 74.4 and $105.8 \mu \mathrm{g} / \mathrm{kg}$ respectively. Consistently, the BAA analog lappaconitine was reported to alleviate morphine and cocaine physical dependence (Qu and $\mathrm{Qu}, 1994)$. On the other respect, daily subcutaneous injections of morphine but not BAA (300 $\mu \mathrm{g} / \mathrm{kg} / \mathrm{day})$ 
for 5 consecutive days induced remarkable CPP acquisition with high conditioning scores. Single subcutaneous injection of BAA $(300 \mu \mathrm{g} / \mathrm{kg})$ entirely abolished morphine-induced CPP acquisition. All these results indicate that BAA does not induce withdrawal signs and CPP acquisition, moreover, it markedly alleviates morphine-induced both physical and psychological dependence.

Opiates such as morphine and heroin, act at the mesolimbic dopamine pathway projecting from ventral tegmental (VTA) to NAc (Patyal et al., 2012). Opiates drugs effectively stimulate dopamine release in NAc within 1 hour after administering intracerebroventricularly or locally into VTA (Murphy et al., 1996; Sebastian et al., 2016). Hippocampal input to the shell of NAc (NAcSh) is important for driving NAc activity which may play a role in reward behaviors (LeGates et al., 2018). Thus, it can be seen that NAc and hippocampus, located around the cerebroventricular area, are important sites for drugs to produce addiction. Dynorphin A regulates the activity of dopamine neurons by acting on $x$-opioid receptors in mesolimbic, NAcSh , prefrontal cortex and VTA that have been implicated in drug abuse liability (Meshul and McGinty, 2000; Volkow et al., 2009). Extracellular dopamine levels in NAc are increased in mice lacking $x$-opioid receptors, revealing that the dynorphin/ $x$-opioid receptor system inhibits dopamine neurotransmission and counteracts the reward of opioid drugs of abuse (Chefer et al., 2005; Shippenberg et al., 2007b). Hippocampal CA1 has been demonstrated in reward-association of learning and memory especially in the CPP model (Fanselow and Dong, 2010; Riahi et al., 2013). The intra-CA1 administration of D1/D2 receptor antagonists SCH23390 and sulpiride, and microinjection of the $x$-opioid receptor agonist U50,488H into NAcSh, resulted in a decrease in morphine conditioning scores (Assar et al., 2016). In this study, we explored whether the dynorphin $\mathrm{A} / x$-opioid receptor system in NAc and hippocampus was closely associated with BAA-attenuated morphine physical dependence and psychological dependence. Subcutaneous injection of BAA in morphinetreated mice stimulated the expression of dynorphin A in NAc and hippocampus at 1 hour after injection, which was in agreement with the time-course of its anti-addictive effects. The results are parallel to the previous findings in which intrathecal and subcutaneous injection of BAA, bullatine A and lappaconitine stimulated the expression of dynorphin but not $\beta$-endorphin in the spinal cord ( $\mathrm{Li}$ et al., 2016a; Li et al., 2016b).

The notion is further supported by the following intervention injections through the cerebroventricular route which is located around NAc and hippocampus. It was previously reported that single intravenous injection of dynorphin A attenuated withdrawal symptoms of morphine physical dependence (Takemori et al., 1993). The present study further demonstrated that intracerebroventricular injection of the dynorphin A antiserum totally eliminated systemic BBA-inhibited morphine withdrawal signs and CPP acquisition. In addition, the highly specific $x$-opioid receptor antagonist GNTI, given intracerebroventricularly, also entirely eliminated systemic BBA-inhibited morphine physical and psychological dependence. The results are in agreement with the previous publications that the $x$-opioid receptor agonist salvinorin A punished self-administration of cocaine and remifentanil in monkeys (Freeman et al., 2014), and that addition of the $x$-opioid receptor agonist U69,593 to fentanyl produced a proportion-dependent decrease of fentanyl self-administration in rats (Negus et al., 2008). In agreement, GNTI and other specific $x$-opioid receptor antagonist nor-BNI (but not the $\mu$ - or $\delta$-opioid receptor antagonist) blocked the antinociceptive effects of BAA (Li et al., 2016b; Huang et al., 2020b), bullatine A (Huang et al., 2016) and lappaconitine (Sun et al., 2018) in the rodent models of neuropathic pain, bone cancer pain, inflammatory pain and visceral pain.

Cumulative evidence indicates that microglia in brain particularly in NAc, VTA and hippocampus are influenced and activated by chronic exposure to abuse drugs such as opiates and alcohol (Miguel-Hidalgo et al., 2002; Hutchinson et al., 2009; Coller and Hutchinson, 2012). Drug abuse activates microglia and produces a large number of inflammatory factors, which affect synapse reconstruction, chemical changes in neural signal transduction and phagocytosis of apoptotic neurons, and ultimately regulate the dopamine reward signaling pathway and enhance drug dependence and addiction (Kovacs, 2012; Garaschuk and Verkhratsky, 2019). On the other hand, recent studies have shown that microglia have an alternative activation state or protective state, which activates anti-inflammatory cascades and exhibits neuroprotection and antinociception (Hu et al., 2012; Fan et al., 2015; Wu et al., 2017; Wu et al., 2018). Our present study provides additional evidence that BAA stimulates microglia to express dynorphin A to attenuate drug dependence 
and addiction. Subcutaneous injection of BAA stimulated dynorphin A expression only in microglia and not in astrocytes and neurons in NAcSh and hippocampal CA1, identified by immunofluorescence staining of dynorphin A with microglial cellular marker Iba-1, astrocytic marker GFAP and neuronal marker NeuN. The results are in agreement with the previous finding in which injection of the BAA analog bullatine A specifically stimulated microglial (but not astrocytic or neural) expression of dynorphin A in the spinal cords of neuropathic rats (Huang et al., 2016). We further demonstrated that intracerebroventricular injection of the microglial activation inhibitor minocycline entirely blocked systemic BAA-inhibited morphine-induced physical and psychological dependence. Consistently, the antinociceptive effects of BAA and its analogs bullatine A and lappaconitine were also blocked by intrathecal injection of minocycline in the rat models of pain hypersensitivity (Huang et al., 2016; Sun et al., 2018a; Huang et al., 2020b). These results highlight that stimulation of microglia expresses and releases dynorphin A, in contrast to proinflammatory cytokines and neurotrophins, and inhibits morphine physical and psychological dependence and pain hypersensitivity.

Drug addiction is a chronically and relapsing disorder characterized by compulsive seeking and taking drugs regardless of the adverse effects it could be cause (Shippenberg et al., 2007b). The main treatment approach for drug addiction is detoxification and relieves withdrawal symptoms, and methadone substitution is most commonly used. This treatment, however, is just provided to inpatients in well-equipped management institutions due to its own physical dependence (Kampman and Jarvis, 2015; Tran et al., 2017). Clonidine is a non-opioid detoxifying agent and diminishes withdrawal symptoms via activation of adrenergic $\alpha_{2}{ }^{-}$ receptors, and is superior to other treatments since it is not addictive and does not produce euphoria, although the side-effect of postural hypotension limits its clinical use (Wilson and DiGeorge, 1993). On the other respect, psychotherapy for addiction should be emphasized conceptually. However, only a few patients are unfortunately willing to undergo it, and many patients are still carving for addictive substances after improving withdrawal symptoms, which eventually leads to relapse (Woody et al., 1983; Arevalo et al., 2008). Thus, the approaches at present to solve opioid addiction especially psychological dependence are limited. Our current study provides a solid pharmacological base for BAA to alleviate both morphine physical and psychological dependence at the animal level. In addition, oral administration of the BAA analog lappaconitine over 6 days reduced or eliminated withdrawal symptoms such as yawing, shedding tears, chilliness, mydriasis and restlessness in drug addict patients whose duration of heroin or opium addiction ranged from 1 to 4 years $(\mathrm{Qu}$ and $\mathrm{Qu}, 1994)$. Taken together, all these results indicate that BAA is a unique and promising clinical development candidate to treat opioid addiction, especially for psychological dependence. The data also suggest that targeting microglial expression and secretion of dynorphin $\mathrm{A}$ is a potential approach for the opioid drug addiction treatment.

\section{Acknowledgements}

This study was supported by a grant from the National Natural Science Foundation of China (\#81673403) and the Shanghai Key Laboratory of Psychotic Disorders (16-K01).

\section{Conflict of interest.}

The authors declare no competing financial interests in this work.

\section{Author contributions}

YXW and MJZ conceived and designed the experiments; MYW, LM and KAA performed the experiments; MJZ, LM and YXW analyzed the data; and YXW and MJZ wrote the paper. All authors read and approved the final manuscript.

\section{References}

Aguilar MA, Rodriguez-Arias M, Minarro J (2009) Neurobiological mechanisms of the reinstatement of drug-conditioned place preference. Brain research reviews 59:253-277.

Arevalo S, Prado G, Amaro H (2008) Spirituality, sense of coherence, and coping responses in women receiving treatment for alcohol and drug addiction. Evaluation and program planning 31:113-123. 
Assar N, Mahmoudi D, Farhoudian A, Farhadi MH, Fatahi Z, Haghparast A (2016) D1- and D2-like dopamine receptors in the CA1 region of the hippocampus are involved in the acquisition and reinstatement of morphine-induced conditioned place preference. Behavioural brain research 312:394-404.

Ayrout M, Le Billan F, Grange-Messent V, Mhaouty-Kodja S, Lombes M, Chauvin S (2019) Glucocorticoids stimulate hypothalamic dynorphin expression accounting for stress-induced impairment of GnRH secretion during preovulatory period. Psychoneuroendocrinology 99:47-56.

Bahi A, Kusnecov A, Dreyer JL (2008) The role of tissue-type plasminogen activator system in amphetamineinduced conditional place preference extinction and reinstatement. Neuropsychopharmacology : official publication of the American College of Neuropsychopharmacology 33:2726-2734.

Beardsley PM, Howard JL, Shelton KL, Carroll FI (2005) Differential effects of the novel kappa opioid receptor antagonist, JDTic, on reinstatement of cocaine-seeking induced by footshock stressors vs cocaine primes and its antidepressant-like effects in rats. Psychopharmacology 183:118-126.

Bello-Ramirez AM, Nava-Ocampo AA (2004) A QSAR analysis of toxicity of Aconitum alkaloids. Fundamental \& clinical pharmacology 18:699-704.

Bobzean SAM, Kokane SS, Butler BD, Perrotti LI (2019) Sex differences in the expression of morphine withdrawal symptoms and associated activity in the tail of the ventral tegmental area. Neuroscience letters 705:124-130.

Bodnar RJ (2010) Endogenous opiates and behavior: 2009. Peptides 31:2325-2359.

Bruchas MR, Land BB, Chavkin C (2010) The dynorphin/kappa opioid system as a modulator of stressinduced and pro-addictive behaviors. Brain research 1314:44-55.

Carey AN, Borozny K, Aldrich JV, Mclaughlin JP (2007) Reinstatement of cocaine place-conditioning prevented by the peptide kappa-opioid receptor antagonist arodyn. European journal of pharmacology 569:8489.

Chartoff EH, Potter D, Damez-Werno D, Cohen BM, Carlezon WA, Jr. (2008) Exposure to the selective kappa-opioid receptor agonist salvinorin A modulates the behavioral and molecular effects of cocaine in rats. Neuropsychopharmacology : official publication of the American College of Neuropsychopharmacology $33: 2676-2687$.

Chefer VI, Czyzyk T, Bolan EA, Moron J, Pintar JE, Shippenberg TS (2005) Endogenous kappa-opioid receptor systems regulate mesoaccumbal dopamine dynamics and vulnerability to cocaine. The Journal of neuroscience : the official journal of the Society for Neuroscience 25:5029-5037.

Coller JK, Hutchinson MR (2012) Implications of central immune signaling caused by drugs of abuse: Mechanisms, mediators and new therapeutic approaches for prediction and treatment of drug dependence. Pharmacology \& therapeutics 134:219-245.

Ezard N, Cecilio ME, Clifford B, Baldry E, Burns L, Day CA, Shanahan M, Dolan K (2018) A managed alcohol program in Sydney, Australia: Acceptability, cost-savings and non-beverage alcohol use. Drug and alcohol review 37 Suppl 1:S184-s194.

Fallon JH, Leslie FM (1986) Distribution of dynorphin and enkephalin peptides in the rat brain. The Journal of comparative neurology 249:293-336.

Fan H, Li TF, Gong N, Wang YX (2015) Shanzhiside methylester, the principle effective iridoid glycoside from the analgesic herb Lamiophlomis rotata, reduces neuropathic pain by stimulating spinal microglial $\beta$-endorphin expression. Neuropharmacology:S0028390815301027.

Fanselow MS, Dong HW (2010) Are the dorsal and ventral hippocampus functionally distinct structures? Neuron 65:7-19. 
Freeman KB, Naylor JE, Prisinzano TE, Woolverton WL (2014) Assessment of the kappa opioid agonist, salvinorin A, as a punisher of drug self-administration in monkeys. Psychopharmacology 231:2751-2758.

Garaschuk O, Verkhratsky A (2019) Physiology of Microglia. Methods in molecular biology (Clifton, NJ) 2034:27-40.

Goeldner C, Lutz PE, Darcq E, Halter T, Clesse D, Ouagazzal AM, Kieffer BL (2011) Impaired emotionallike behavior and serotonergic function during protracted abstinence from chronic morphine. Biological psychiatry 69:236-244.

Gouveia K, Hurst JL Optimising reliability of mouse performance in behavioural testing: the major role of non-aversive handling. Scientific Reports 7:44999.

Hooke LP, He L, Lee NM (1995) Dynorphin A modulates acute and chronic opioid effects. Journal of Pharmacology \& Experimental Therapeutics 273:292-297.

Hu X, Li P, Guo Y, Wang H, Leak RK, Chen S, Gao Y, Chen J (2012) Microglia/macrophage polarization dynamics reveal novel mechanism of injury expansion after focal cerebral ischemia. Stroke 43:3063-3070.

Huang Q, Sun ML, Chen Y, Li XY, Wang YX (2017a) Concurrent bullatine A enhances morphine antinociception and inhibits morphine antinociceptive tolerance by indirect activation of spinal kappa-opioid receptors. Journal of ethnopharmacology 196:151-159.

Huang Q, Mao XF, Wu HY, Li TF, Sun ML, Liu H, Wang YX (2016) Bullatine A stimulates spinal microglial dynorphin A expression to produce anti-hypersensitivity in a variety of rat pain models. Journal of Neuroinflammation 13.

Huang Q, Mao XF, Wu HY, Liu H, Sun ML, Wang X, Wang YX (2017b) Cynandione A attenuates neuropathic pain through p38beta MAPK-mediated spinal microglial expression of beta-endorphin. Brain, behavior, and immunity 62:64-77.

Huang S-N, Wei J, Huang L-T, Ju P-J, Chen J, Wang Y-X (2020a) Bulleyaconitine A Inhibits Visceral Nociception and Spinal Synaptic Plasticity through Stimulation of Microglial Release of Dynorphin A. Neural Plasticity 2020:1484087.

Huang SN, Yang B, Ma L, Huang LT, Ju PJ, Wei J, Ali U, Wang YX, Chen J (2020b) Bulleyaconitine A Exerts Antianxiety and Antivisceral Hypersensitivity Effects. Frontiers in pharmacology 11:328.

Hutchinson MR, Lewis SS, Coats BD, Skyba DA, Crysdale NY, Berkelhammer DL, Brzeski A, Northcutt A, Vietz CM, Judd CM, Maier SF, Watkins LR, Johnson KW (2009) Reduction of opioid withdrawal and potentiation of acute opioid analgesia by systemic AV411 (ibudilast). Brain, behavior, and immunity 23:240250 .

Hylden JL, Wilcox GL (1980) Intrathecal morphine in mice: a new technique. European journal of pharmacology 67:313-316.

Kampman K, Jarvis M (2015) American Society of Addiction Medicine (ASAM) National Practice Guideline for the Use of Medications in the Treatment of Addiction Involving Opioid Use. Journal of addiction medicine 9:358-367.

Khaleghzadeh-Ahangar H, Haghparast A (2015) Intra-accumbal CB1 receptor blockade reduced extinction and reinstatement of morphine. Physiology \& behavior 149:212-219.

Khaleghzadeh-Ahangar H, Haghparast A (2017) Intra-accumbal Cannabinoid Agonist Attenuated Reinstatement but not Extinction Period of Morphine-Induced Conditioned Place Preference; Evidence for Different Characteristics of Extinction Period and Reinstatement. Neurochemical research 42:3321-3330.

Kobayashi K, Imagama S, Ohgomori T, Hirano K, Uchimura K, Sakamoto K, Hirakawa A, Takeuchi H, Suzumura A, Ishiguro N, Kadomatsu K (2013) Minocycline selectively inhibits M1 polarization of microglia. 
Cell Death Dis 4:e525.

Kovacs KJ (2012) Microglia and drug-induced plasticity in reward-related neuronal circuits. Frontiers in molecular neuroscience 5:74.

LeGates TA, Kvarta MD, Tooley JR, Francis TC, Lobo MK, Creed MC, Thompson SM (2018) Reward behaviour is regulated by the strength of hippocampus-nucleus accumbens synapses. Nature 564:258-262.

Leitermann RJ, Terashvili M, Mizoguchi H, Wu HE, Chen F, Clithero A, Tseng LF (2004) Increased release of immunoreactive dynorphin A1-17 from the spinal cord after intrathecal treatment with endomorphin-2 in anesthetized rats. European journal of pharmacology 504:177-183.

Lenard NR, Roerig SC (2005) Development of antinociceptive tolerance and physical dependence following morphine i.c.v. infusion in mice. European journal of pharmacology 527:71-76.

Li T-F, Gong N, Wang Y-X (2016a) Ester Hydrolysis Differentially Reduces Aconitine-Induced Antihypersensitivity and Acute Neurotoxicity: Involvement of Spinal Microglial Dynorphin Expression and Implications for Aconitum Processing. Frontiers in pharmacology 7:367-367.

Li TF, Fan H, Wang YX (2016b) Aconitum-Derived Bulleyaconitine A Exhibits Antihypersensitivity Through Direct Stimulating Dynorphin A Expression in Spinal Microglia. The journal of pain : official journal of the American Pain Society 17:530-548.

Li TF, Wu HY, Wang YR, Li XY, Wang YX (2017) Molecular signaling underlying bulleyaconitine A (BAA)-induced microglial expression of prodynorphin. Sci Rep 7:45056.

Liu R, Huang X-P, Yeliseev A, Xi J, Roth B (2013) Novel Molecular Targets of Dezocine and Their Clinical Implications. Anesthesiology 120.

Maisonneuve IM, Archer S, Glick SD (1994) U50,488, a kappa opioid receptor agonist, attenuates cocaineinduced increases in extracellular dopamine in the nucleus accumbens of rats. Neuroscience letters 181:57-60.

Marszalek-Grabska M, Gibula-Bruzda E, Bodzon-Kulakowska A, Suder P, Gawel K, Filarowska J, Listos J, Danysz W, Kotlinska JH (2018) Effects of the Positive Allosteric Modulator of Metabotropic Glutamate Receptor 5, VU-29, on Impairment of Novel Object Recognition Induced by Acute Ethanol and Ethanol Withdrawal in Rats. Neurotoxicity research 33:607-620.

Meng J, Zhang X, Wu H, Bu J, Shi C, Deng C, Mao Y (2012) Morphine-induced conditioned place preference in mice: Metabolomic profiling of brain tissue to find "molecular switch" of drug abuse by gas chromatography/mass spectrometry. Analytica Chimica Acta 710:125-130.

Meshul CK, McGinty JF (2000) Kappa opioid receptor immunoreactivity in the nucleus accumbens and caudate-putamen is primarily associated with synaptic vesicles in axons. Neuroscience 96:91-99.

Miguel-Hidalgo JJ, Wei J, Andrew M, Overholser JC, Jurjus G, Stockmeier CA, Rajkowska G (2002) Glia pathology in the prefrontal cortex in alcohol dependence with and without depressive symptoms. Biological psychiatry 52:1121-1133.

Murphy NP, Ly HT, Maidment NT (1996) Intracerebroventricular orphanin FQ/nociceptin suppresses dopamine release in the nucleus accumbens of anaesthetized rats. Neuroscience 75:1-4.

Mysels D, Sullivan MA (2009) The kappa-opiate receptor impacts the pathophysiology and behavior of substance use. The American journal on addictions 18:272-276.

Negus SS, Schrode K, Stevenson GW (2008) Micro/kappa opioid interactions in rhesus monkeys: implications for analgesia and abuse liability. Experimental and clinical psychopharmacology 16:386-399.

Nestler EJ, Hope BT, Widnell KL (1993) Drug addiction: a model for the molecular basis of neural plasticity. Neuron 11:995-1006. 
Nocjar C, Zhang J, Feng P, Panksepp J (2012) The social defeat animal model of depression shows diminished levels of orexin in mesocortical regions of the dopamine system, and of dynorphin and orexin in the hypothalamus. Neuroscience 218:138-153.

Patyal R, Woo EY, Borgland SL (2012) Local hypocretin-1 modulates terminal dopamine concentration in the nucleus accumbens shell. Frontiers in behavioral neuroscience 6:82.

Pfeiffer A, Brantl V, Herz A, Emrich HM (1986) Psychotomimesis mediated by kappa opiate receptors. Science (New York, NY) 233:774-776.

Qi C, Guo B, Ren K, Yao H, Wang M, Sun T, Cai G, Liu H, Li R, Luo C, Wang W, Wu S (2018) Chronic inflammatory pain decreases the glutamate vesicles in presynaptic terminals of the nucleus accumbens. Molecular pain 14:1744806918781259.

$\mathrm{Qu} \mathrm{Y,} \mathrm{Qu} \mathrm{P} \mathrm{(1994)} \mathrm{Aconitane} \mathrm{derivatives} \mathrm{used} \mathrm{as} \mathrm{a} \mathrm{medication} \mathrm{to} \mathrm{treat} \mathrm{addiction.} \mathrm{In:} \mathrm{US} \mathrm{Patent} \mathrm{NO:}$ $5,290,784$.

Reiss D, Ceredig RA, Secher T, Boue J, Barreau F, Dietrich G, Gaveriaux-Ruff C (2017) Mu and delta opioid receptor knockout mice show increased colonic sensitivity. European journal of pain (London, England) 21:623-634.

Riahi E, Khodagholi F, Haghparast A (2013) Role of dorsal hippocampal orexin-1 receptors in associating morphine reward with contextual stimuli. Behavioural pharmacology 24:237-248.

Robbins TW, Ersche KD, Everitt BJ (2008) Drug addiction and the memory systems of the brain. Annals of the New York Academy of Sciences 1141:1-21.

Ruzza C, Holanda VA, Gavioli EC, Trapella C, Calo G (2019) NOP agonist action of cebranopadol counteracts its liability to promote physical dependence. Peptides 112:101-105.

Schwarzer C (2009) 30 years of dynorphins-new insights on their functions in neuropsychiatric diseases. Pharmacology \& therapeutics 123:353-370.

Sebastian, T., Peters, Michael, T., Bowen, Kathrin, Bohrer, Iain, S. (2016) Oxytocin inhibits ethanol consumption and ethanol-induced dopamine release in the nucleus accumbens. Addiction Biology.

Shi X, Barr JL, von Weltin E, Wolsh C, Unterwald EM (2019) Differential Roles of Accumbal GSK3beta in Cocaine versus Morphine-Induced Place Preference, U50,488H-Induced Place Aversion, and Object Memory. The Journal of pharmacology and experimental therapeutics 371:339-347.

Shippenberg TS, Zapata A, Chefer VI (2007a) Dynorphin and the pathophysiology of drug addiction. Pharmacology \& Therapeutics 116:306-321.

Shippenberg TS, Zapata A, Chefer VI (2007b) Dynorphin and the pathophysiology of drug addiction. Pharmacology \& therapeutics 116:306-321.

Shirazy M, RayatSanati K, Jamali S, Motamedi F, Haghparast A (2020) Role of orexinergic receptors in the dentate gyrus of the hippocampus in the acquisition and expression of morphine-induced conditioned place preference in rats. Behavioural brain research 379:112349.

Sun M-L, Ao J-P, Wang Y-R, Huang Q, Li T-F, Li X-Y, Wang Y-X (2018a) Lappaconitine, a C18-diterpenoid alkaloid, exhibits antihypersensitivity in chronic pain through stimulation of spinal dynorphin A expression. Psychopharmacology 235:2559-2571.

Takemori AE, Loh HH, Lee NM (1993) Suppression by dynorphin A and [des-Tyr1]dynorphin A peptides of the expression of opiate withdrawal and tolerance in morphine-dependent mice. The Journal of pharmacology and experimental therapeutics 266:121-124.

Tang XC, Liu XJ, Wei-Hua LU, Wang MD, Ai-Ling LI (1986) STUDIES ON THE ANALGESIC ACTION AND PHYSICAL DEPENDENCE OF BULLEYACONITINE A. Acta Pharmaceutica Sinica. 
Tran TH, Griffin BL, Stone RH, Vest KM, Todd TJ (2017) Methadone, Buprenorphine, and Naltrexone for the Treatment of Opioid Use Disorder in Pregnant Women. Pharmacotherapy 37:824-839.

Volkow ND, Fowler JS, Wang GJ, Baler R, Telang F (2009) Imaging dopamine's role in drug abuse and addiction. Neuropharmacology 56 Suppl 1:3-8.

Wahlert A, Funkelstein L, Fitzsimmons B, Yaksh T, Hook V (2013) Spinal astrocytes produce and secrete dynorphin neuropeptides. Neuropeptides 47:109-115.

Wakabayashi Y, Nakada T, Murata K, Ohkura S, Mogi K, Navarro VM, Clifton DK, Mori Y, Tsukamura H, Maeda K, Steiner RA, Okamura H (2010) Neurokinin B and dynorphin A in kisspeptin neurons of the arcuate nucleus participate in generation of periodic oscillation of neural activity driving pulsatile gonadotropinreleasing hormone secretion in the goat. The Journal of neuroscience : the official journal of the Society for Neuroscience 30:3124-3132.

Wang CF, Gerner P, Wang SY, Wang GK (2007) Bulleyaconitine A isolated from aconitum plant displays long-acting local anesthetic properties in vitro and in vivo. Anesthesiology 107:82-90.

Wilson RS, DiGeorge WS (1993) Methadone combined with clonidine versus clonidine alone in opiate detoxification. Journal of substance abuse treatment 10:529-535.

Wingo T, Nesil T, Choi JS, Li MD (2016) Novelty Seeking and Drug Addiction in Humans and Animals: From Behavior to Molecules. Journal of neuroimmune pharmacology : the official journal of the Society on NeuroImmune Pharmacology 11:456-470.

Woody GE, Luborsky L, McLellan AT, O'Brien CP, Beck AT, Blaine J, Herman I, Hole A (1983) Psychotherapy for opiate addicts. Does it help? Archives of general psychiatry 40:639-645.

Wu D, Teismann P, Ischiropoulos H, Vilaperelló M, Przedborski S, Tieu K, Vadseth C, Jacksonlewis V, Choi DH (2002) Blockade of microglial activation is neuroprotective in the 1-methyl-4-phenyl-1,2,3,6tetrahydropyridine mouse model of Parkinson disease. 22:1763.

Wu HY, Tang XQ, Mao XF, Wang YX (2017) Autocrine Interleukin-10 Mediates Glucagon-Like Peptide1 Receptor-Induced Spinal Microglial $\beta$-Endorphin Expression. The Journal of neuroscience : the official journal of the Society for Neuroscience 37:11701-11714.

Wu HY, Mao XF, Tang XQ, Usman A, Evhy A, Hao L, Li XY, Wang YX (2018) Spinal interleukin-10 produces antinociception in neuropathy through microglial $\beta$-endorphin expression, separated from antineuroinflammation. Brain Behavior \& Immunity:S0889159118302319-.

Wu X, Zhao N, Bai F, Li C, Liu C, Wei J, Zong W, Yang L, Ryabinin AE, Ma Y, Wang J (2016) Morphineinduced conditioned place preference in rhesus monkeys: Resistance to inactivation of insula and extinction. Neurobiology of Learning and Memory 131:192-200.

Xie MX, Zhu HQ, Pang RP, Wen BT, Liu XG (2018) Mechanisms for therapeutic effect of bulleyaconitine A on chronic pain. Molecular pain 14:1744806918797243.

Yamada K, Ono Y, Kubo KY, Yamamoto T, Onozuka M (2013) Occlusal Disharmony Transiently Impairs Learning and Memory in the Mouse by Increasing Dynorphin A Levels in the Amygdala. The Tohoku journal of experimental medicine 230:49-57.

Yuferov V, Fussell D, LaForge KS, Nielsen DA, Gordon D, Ho A, Leal SM, Ott J, Kreek MJ (2004) Redefinition of the human kappa opioid receptor gene (OPRK1) structure and association of haplotypes with opiate addiction. Pharmacogenetics 14:793-804.

Zhang H, Shi Y-G, Woods J, Watson S, Ko M-C (2007) Central kappa-opioid receptor-mediated antidepressant-like effects of nor-Binaltorphimine: behavioral and BDNF mRNA expression studies. European journal of pharmacology 570:89-96. 
Zhang JY, Gong N, Huang JL, Guo LC, Wang YX (2013) Gelsemine, a principal alkaloid from Gelsemium sempervirens Ait., exhibits potent and specific antinociception in chronic pain by acting at spinal alpha 3 glycine receptors. Pain 154:2452-2462.

Zhu X, Sun W, Li X, Tan S, Zhang X (2015) Effects of spatial memory on morphine CPP and locomotor sensitization in mice. Physiology \& behavior 149:187-191.

\section{Figure legends}

Fig. 1. Inhibitory effects of subcutaneous injection of bulleyaconitine A on naloxone-induced withdrawal signs, including shakes (A ), jumps (B), genital licks (C), fecal excretion (D) and body weight loss (E), in morphine physical dependence mice. Mice were subjected to bi-daily subcutaneous injections of normal saline $(10 \mathrm{~mL} / \mathrm{kg})$, BAA $(300 \mu \mathrm{g} / \mathrm{kg})$ or morphine (escalating doses of 5, 10, 20, 40, 80 and $100 \mathrm{mg} / \mathrm{kg}$ ) for 6 days. On the 7th day, mice received intraperitoneal injection of naloxone $(5 \mathrm{mg} / \mathrm{kg}) 4$ hours post last injection of morphine $(100 \mathrm{mg} / \mathrm{kg})$ to induce physical dependence, and their withdrawal signs were observed immediately for 30 minutes. For BAA inhibitory effects, mice received a single injection of saline $(10 \mathrm{~mL} / \mathrm{kg})$ or BAA $(30,100$ or $300 \mu \mathrm{g} / \mathrm{kg}) 40$ minutes prior to naloxone intraperitoneal injection. Dose-response analysis was best projected by the nonlinear least squares methods in $\mathrm{A}$ and $\mathrm{E}$. The data are presented as means \pm S.E.M ( $\mathrm{n}=10$ per group). ${ }^{*},{ }^{\#} \mathrm{P}<0.05$, compared with the saline control group and morphine physical dependence group, respectively, by one-way ANOVA followed by the post-hoc Student-Newman-Keuls test.

Fig. 2. Inhibitory effects of subcutaneous injection of bulleyaconitine A (BAA, $300 \mu \mathrm{g} / \mathrm{kg}$ ) on morphineinduced conditioned place preference (CPP) acquisition in mice. Mice were subjected to alternate daily subcutaneous injections of normal saline $(10 \mathrm{~mL} / \mathrm{kg} /$ day $)$, BAA $(300 \mu \mathrm{g} / \mathrm{kg} /$ day $)$ or morphine $(10 \mathrm{mg} / \mathrm{kg} /$ day $)$ for 5 days followed by a single subcutaneous injection of saline $(10 \mathrm{~mL} / \mathrm{kg})$ or BAA $(300 \mu \mathrm{g} / \mathrm{kg})$. Results are presented as means \pm S.E.M. ( $\mathrm{n}=12$ per group). ${ }^{*},{ }^{*} \mathrm{P}<0.05$ compared to the saline control and morphine CPP control groups, respectively, by one-way ANOVA followed by the post-hoc Student-Newman-Keuls test.

Fig. 3. Stimulatory effects of subcutaneous injection of bulleyaconitine A (BAA, $300 \mu \mathrm{g} / \mathrm{kg}$ ) on gene (A , B ) and protein (C, D ) expression of dynorphin A in nucleus accumbens (NAc) and hippocampus in multiple daily morphine $(10 \mathrm{mg} / \mathrm{kg})$-treated mice. The mRNA and protein expression of dynorphin A was measured using quantitative real-time PCR and fluorescent ELISA kit, respectively. Data are presented as mean \pm S.E.M ( $\mathrm{n}=8$-12 per group). ${ }^{*} \mathrm{P}<0.05$ compared to the saline control group, by unpaired and two-tailed Student t-test.

Fig. 4. Specific stimulatory effects of subcutaneous injection of bulleyaconitine A (BAA, $300 \mu \mathrm{g} / \mathrm{kg}$ ) on dynorphin A expression in microglia, but not in astrocytes or neurons in the shell of nucleus accumbens (NAcSh) in multiple daily morphine $(10 \mathrm{mg} / \mathrm{kg})$-treated mice. Frozen sections of NAcSh were obtained 1 hour after subcutaneous injection of saline $(10 \mathrm{~mL} / \mathrm{kg})$ or BAA $(300 \mu \mathrm{g} / \mathrm{kg})$. Immunofluorescence was doubly stained with dynorphin A/microglial marker Iba-1 (A ,B, G , H ), dynorphin A/astrocytic marker GFAP $(\mathbf{C}, \mathbf{D}, \mathbf{I}, \mathbf{J})$ and dynorphin $\mathrm{A} /$ neuronal marker $\operatorname{NeuN}(\mathbf{E}, \mathbf{F}, \mathbf{K}, \mathbf{L})$ under $10 \times$ magnification (scale bar: $250 \mu \mathrm{m}$ ) and $30 \times$ magnification (scale bar: $50 \mu \mathrm{m}$ ), respectively. Arrowheads indicate colocalization of dynorphin A with microglia, astrocytes or neurons. Colocalized areas of dynorphin A/Iba-1 (M), dynorphin A/GFAP (N) and dynorphin A/NeuN (O ) were quantified at $10 \times$ magnification using the ImageJ software. Data are presented as mean \pm S.E.M. ( $\mathrm{n}=6$ per group). ${ }^{*} \mathrm{P}<0.05$ compared to the saline control group, by unpaired and two-tailed Student t-test.

Fig. 5. Specific stimulatory effects of subcutaneous injection of bulleyaconitine A (BAA, $300 \mu \mathrm{g} / \mathrm{kg}$ ) on dynorphin A expression in microglia, but not in astrocytes or neurons in hippocampal CA1 in multiple twice-daily morphine $(10 \mathrm{mg} / \mathrm{kg})$-treated mice. Frozen sections of hippocampal CA1 were obtained 1 hour after subcutaneous injection of saline $(10 \mathrm{~mL} / \mathrm{kg})$ or BAA $(300 \mu \mathrm{g} / \mathrm{kg})$. Immunofluorescence was doubly stained with dynorphin A/microglial marker Iba-1 (A, B, G , H ), dynorphin A/astrocytic marker GFAP $(\mathbf{C}, \mathbf{D}, \mathbf{I}, \mathbf{J})$ and dynorphin $\mathrm{A} /$ neuronal marker $\operatorname{NeuN}(\mathbf{E}, \mathbf{F}, \mathbf{K}, \mathbf{L})$ under $10 \times$ magnification (scale bar: $250 \mu \mathrm{m}$, DAPI was also colabeled with the nucleus in blue) and $30 \times$ magnification (scale bar: 50 $\mu \mathrm{m})$, respectively. Arrowheads indicate colocalization of dynorphin A with microglia, astrocytes or neurons. 
Colocalized areas of dynorphin A/Iba-1 (M), dynorphin A/GFAP (N) and dynorphin A/NeuN $(\mathbf{O})$ were quantified at $10 \times$ magnification using the ImageJ software. Data are presented as mean \pm S.E.M. $(\mathrm{n}=6$ per group). ${ }^{*} \mathrm{P}<0.05$ compared to the saline control group, by unpaired and two-tailed Student t-test.

Fig. 6. Blockade effects of intracerebroventricular (icv) injection of the microglial activation inhibitor minocycline (A-E ), specific dynorphin A antiserum (F-J ) and selective $x$-opioid receptor antagonist GNTI (K-O ) on subcutaneous (sc) injection of bulleyaconitine A (BAA)-attenuated withdrawal signs in morphine physical dependence mice. Naloxone-induced withdrawal signs included shakes (A, F, K), jumps (B, G, L), genital licks $(\mathrm{C}, \mathrm{H}, \mathrm{M})$, fecal excretion $(\mathrm{D}, \mathrm{I}, \mathrm{N})$ and body weight loss $(\mathrm{E}, \mathrm{J}, \mathrm{O})$. The data are presented as means \pm S.E.M. ( $\mathrm{n}=10$ per group). ${ }^{*}, \# \mathrm{P}<0.05$, compared to the saline control group and BAA group, respectively, by one-way ANOVA followed by the post-hoc Student-Newman-Keuls test.

Fig. 7. Blockade effects of intracerebroventricular (icv) injection of the microglial activation inhibitor minocycline (A), specific dynorphin A antiserum (B ) and selective $x$-opioid receptor antagonist GNTI (C) on subcutaneous (sc) injection of bulleyaconitine A (BAA)-attenuated conditioned place preference (CPP) acquisition in mice. The data are presented as means \pm S.E.M. ( $\mathrm{n}=10$ per group). ${ }^{*},{ }^{*} \mathrm{P}<0.05$, compared to the saline control group and BAA group, respectively, by one-way ANOVA followed by the post-hoc Student-Newman-Keuls test.

Fig. 1

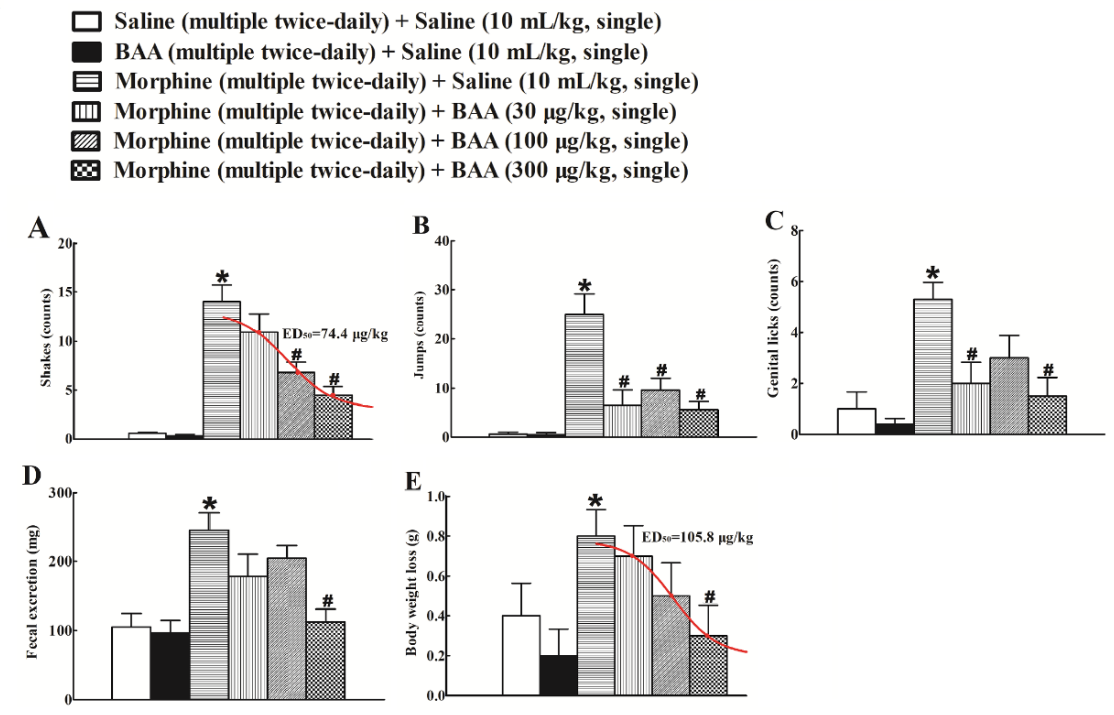

Fig. 2 
Saline (10 mL/kg/day, qd) + Saline (10 mL/kg, single)

$\square$ BAA $(300 \mu \mathrm{g} / \mathrm{kg} / \mathrm{day}, \mathrm{qd})+$ Saline $(10 \mathrm{~mL} / \mathrm{kg}$, single $)$

$\square$ Morphine $(10 \mathrm{mg} / \mathrm{kg} / \mathrm{day}, \mathrm{qd})+$ Saline $(10 \mathrm{~mL} / \mathrm{kg}$, single $)$

$\triangle$ Morphine (10 mg/kg/day, qd) + BAA (300 $\mu \mathrm{g} / \mathrm{kg}$, single)

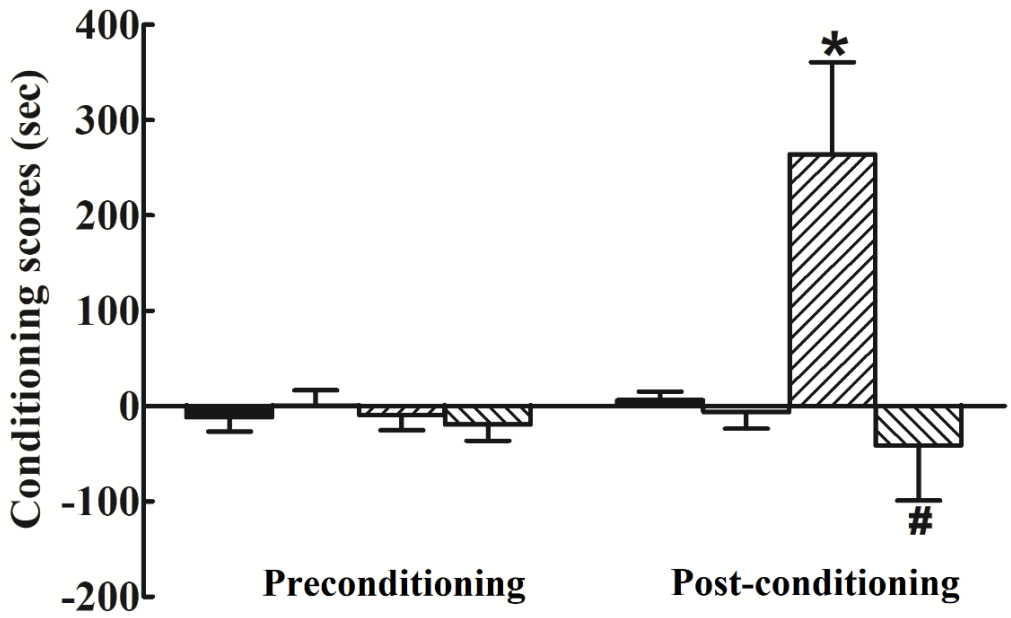

Fig. 3
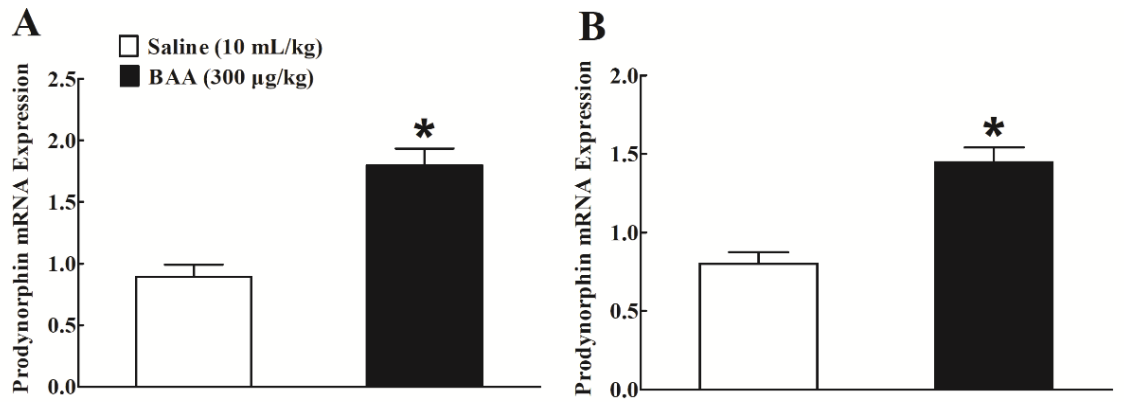

C

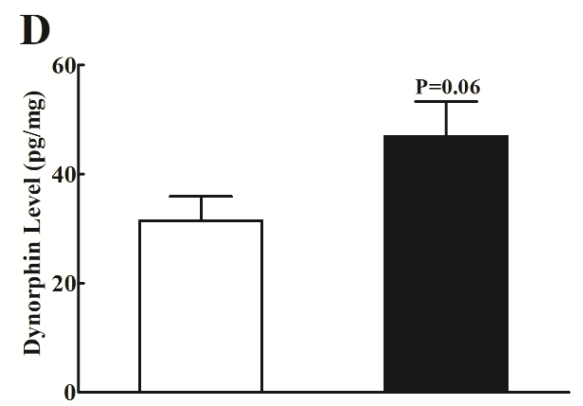

Fig. 4 


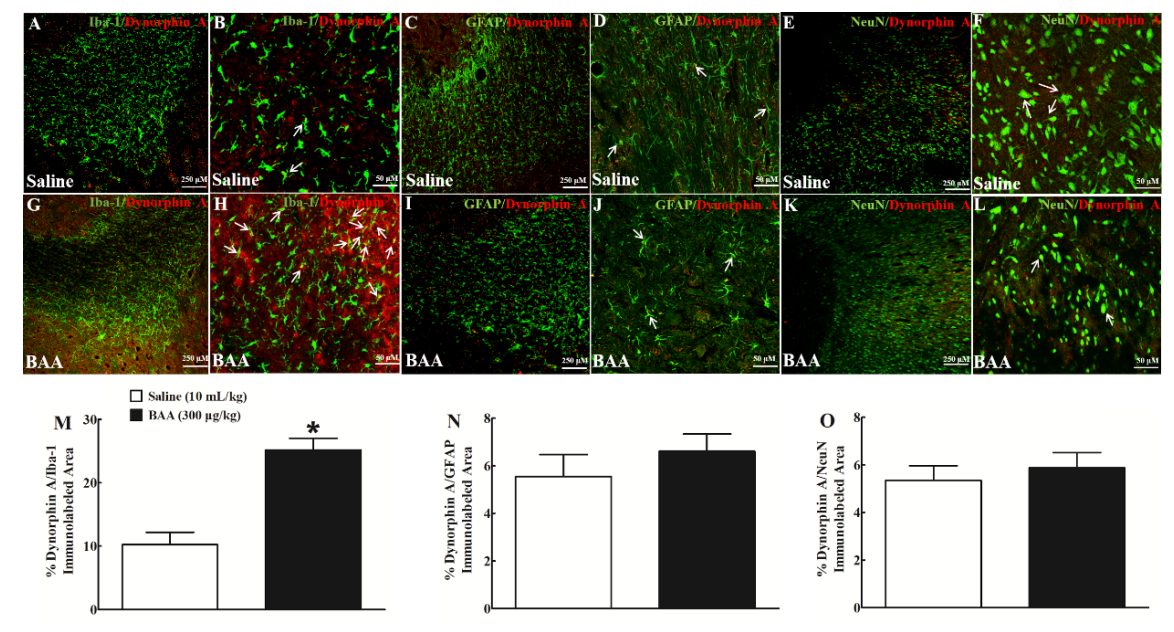

Fig. 5
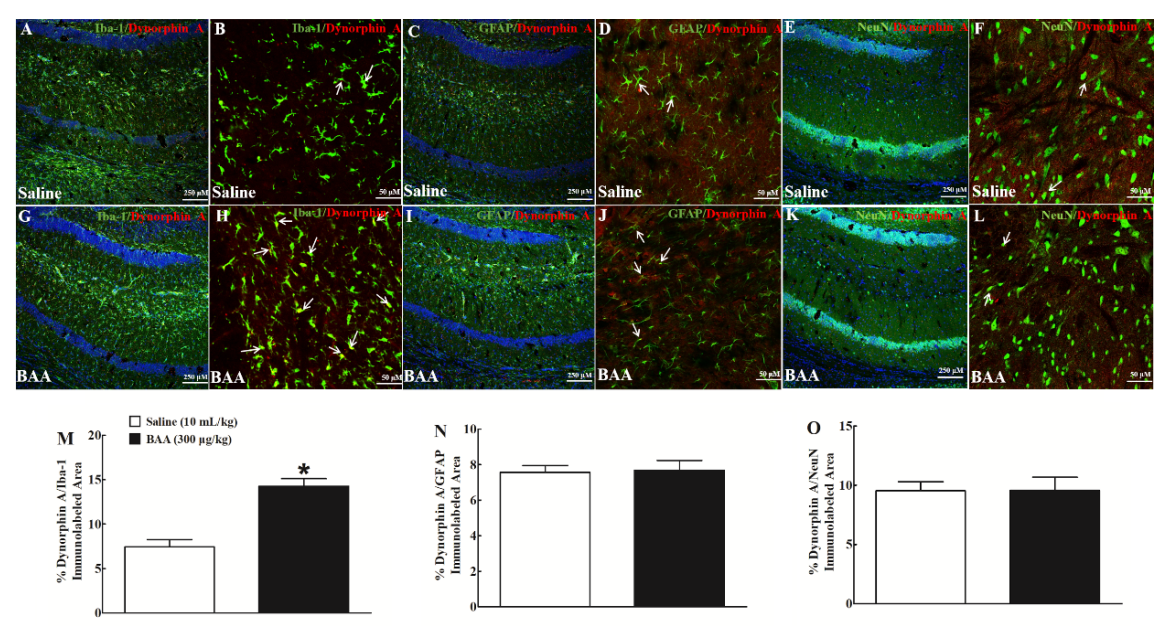

Fig. 6 


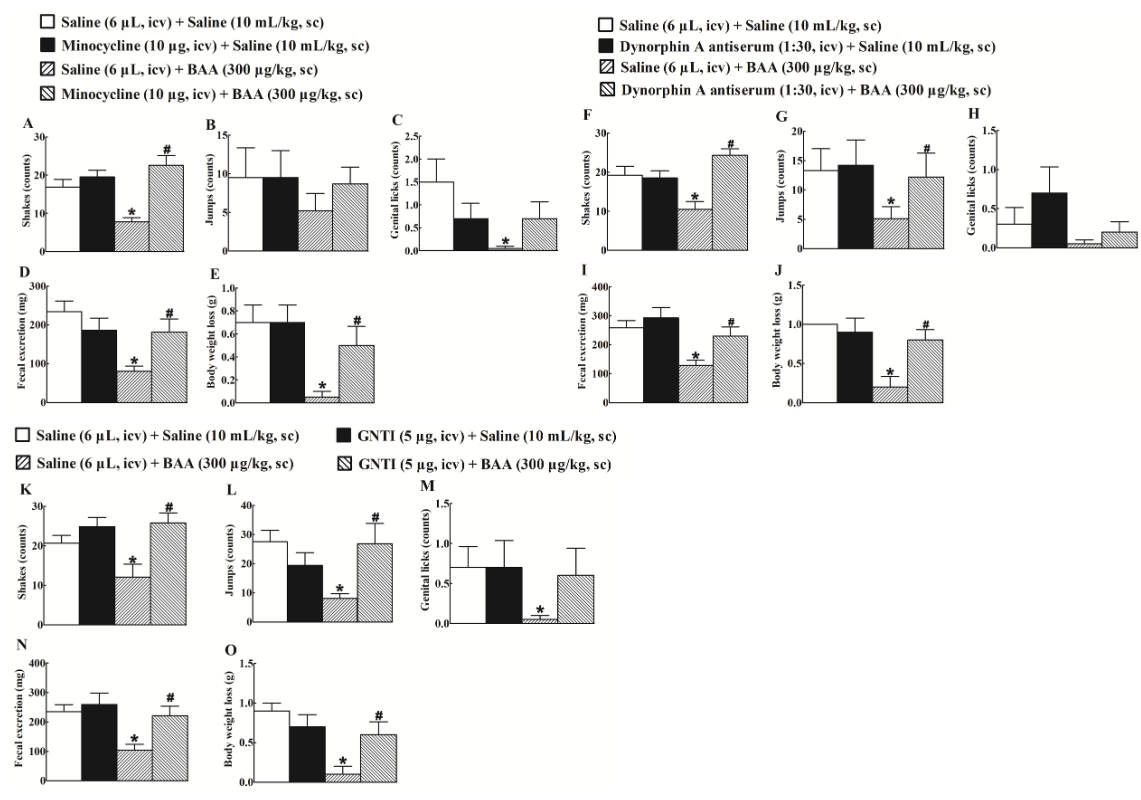

Fig. 7
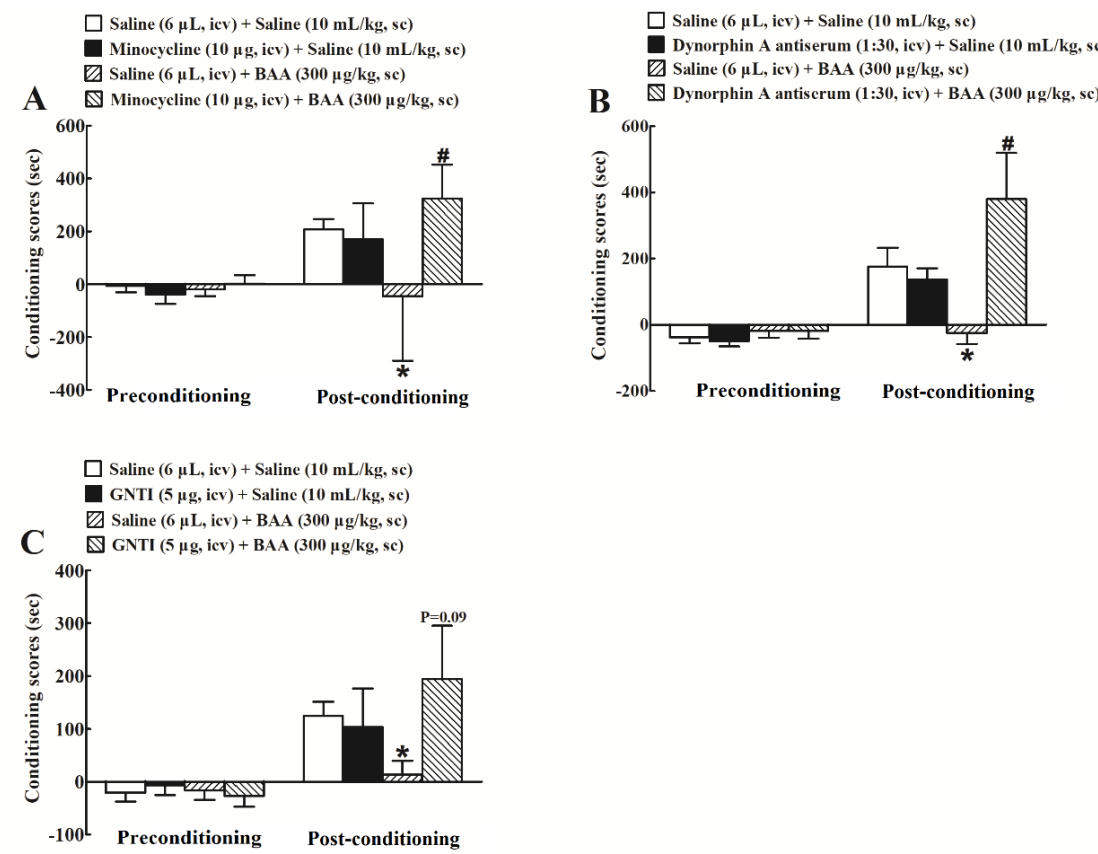

\section{Hosted file}

Desktop.rar available at https://authorea.com/users/338568/articles/465054-bulleyaconitine-ainhibits-morphine-physical-and-psychological-dependence-via-dynorphin-a-expression 